\title{
Age-Related Changes of the Haematological Profile in Green Iguana (Iguana iguana rhinolopha)
}

\author{
S. PEJŘILOVÁ ${ }^{1}$, Z. KNOTKOVÁ ${ }^{1}$, Z. KNOTEK ${ }^{2}$, V. VRBAS 3 \\ ${ }^{1}$ Department of Physiology, ${ }^{2}$ Avian and Exotic Animal Clinic, Faculty of Veterinary Medicine, \\ University of Veterinary and Pharmaceutical Sciences Brno; ${ }^{3}$ Veterinary Research Institute Brno \\ Received January 28, 2004 \\ Accepted June 17, 2004
}

Abstract

Pejřilová S., Z. Knotková, Z. Knotek, V. Vrbas: Age-related Changes of the Haematological Profile in Green Iguana (Iguana iguana rhinolopha). Acta Vet Brno 2004, 73: 305-312.

Most haematological trials focusing on green iguanas have had the form of one-off blood sample-taking analysis. Our project therefore set out to perform a long-term ontogenetic trial on blood-related animals kept in identical conditions. The trial involved 11 green iguanas (Iguana iguana rhinolopha), 5 males and 6 females, from a single clutch. The reptiles were kept in experimental terraria with a specific light regime $(12 \mathrm{~h} / 12 \mathrm{~h})$, at temperature ranging from 24 to 35 ${ }^{\circ} \mathrm{C}$ and air humidity from 60 to $80 \%$. The health status of the iguanas was monitored at regular intervals. At the age of 14 to 36 months, the iguanas were sampled for blood at intervals of at least 30 days. Total red blood cell and white blood cells counts were performed manually, using haemocytometer with the Natt and Herrick's solution; packed cell volume (PCV) was established using the microhaematocrit method; haemoglobin concentration was determined spectrophotometrically by using a standard cyanmethaemoglobin method. The leukocyte differential counts were evaluated and the mean corpuscular volume (MCV), mean corpuscular haemoglobin $(\mathrm{MCH})$ and mean corpuscular haemoglobin concentration (MCHC) were established. No seasonal changes of the haematological indices were observed. No significant differences in the haematological indices between male and female subpopulations were found. As to the number of erythrocytes, a statistically significant drop $(p<0.01)$ was observed comparing the data at 14 to 15 months of age $\left(1.64 \pm 0.58 ; 1.17 \pm 0.1810^{12} / 1\right)$ with those at 34 to 36 months $\left(1.01 \pm 0.14 ; 0.88 \pm 0.12 ; 0.93 \pm 0.0810^{12} / 1\right)$. Apart from that, we recorded a statistically significant $(p<0.01)$ drop in packed cell volume (PCV) comparing the figures at 14 to 18 months $(0.39 \pm 0.04$; $0.38 \pm 0.03 ; 0.39 \pm 0.041 / 1)$ with those obtained at 34 to 35 months of age of the animals $(0.32 \pm 0.03$; $0.35 \pm 0.021 / 1)$. On the other hand, our results confirmed a statistically significant $(p<0.01)$ rise in haemoglobin concentration comparing the data at 23 to 24 months $(73.1 \pm 7.2 ; 64.5 \pm 8.8 \mathrm{~g} / \mathrm{l})$ with those at 35 to 36 months $(92.5 \pm 7.4 ; 94.0 \pm 4.6 \mathrm{~g} / \mathrm{l})$. A similar statistically significant rise $(p<0.01)$ was confirmed for computed red cell indices (MCV, MCH, MCHC), too. The physiological basis underlying these changes remains to be examined in the future.

Reptiles, blood, erythrocytes, haemoglobin, leukocyte differential counts

There is a number of factors complicating interpretation of tests in reptiles. One of the main sources of difficulty is the fact that establishing normal reference values for exotic animals is a complicated task (Walton 2001). Apart from mature blood cells, periferal blood of healthy reptiles contains immature elements, too (Sypek and B ory senko 1988; Frye 1991; Campbell 1996). Automated methods for determining total erythrocyte and leukocyte counts in reptiles fail to account for the nuances resulting from the fact that all the cells in the peripheral blood are nucleated. Values obtained in this way can thus be regarded only as preliminary. For this reason, manual methods for obtaining total counts of blood cells are recommended. The same methodological procedures as those used for quantification of blood cells in avian haematology are used (Barten 1993; Campbell 1996). Interpreting

Address for correspondence:

MVDr. Simona Pejfiilová

Small Animal Clinic

University of Veterinary and Pharmaceutical Sciences Brno

Palackého 1-3, 612 42 Brno

Czech Republic

Phone: +420541562378

Fax: +420 549248841

E-mail: pejrilovas@vfu.cz 
the erythron, we need to know the total red blood cell count, haemoglobin concentration, and packed cell volume to be able to determine important indices (MCV, MCH, MCHC) characterizing the function value of red blood cells and provide a basis for classification of anaemias (Frye 1991; Campbell 1996). Haematological parameters in healthy reptiles may be influenced by a number of internal and environmental factors (Frye 1991; Anderson 1992; Barten 1993).

Haematology of green iguanas has been a subject of interest for a number of authors; the results of trials show a significant degree of variation due to different animal selection methods and technical differences in blood sample treatment (Divers et al. 1996; Köhler 1996; Redrobe and MacDonald 1999; Harr et al. 2001; Knotek et al. 2002, 2003). Most trials so far consisted in analysing blood from one-off sample-takings. The goal of our trial therefore was performing a long-term ontogenetic study on blood-related animals kept in identical conditions.

\section{Materials and Methods}

Animals

At its start, the trial included 12 green iguanas (Iguana iguana rhinolopha), 6 males and 6 females, from a single clutch in Brno ZOO. Aged 10 months, the iguanas were placed in experimental rooms of the Department of Physiology of the University of Veterinary and Pharmaceutical Sciences Brno to be kept in terraria $(75 \times 85 \times 85$ $\mathrm{cm})$ with a specific light regime ( $12 \mathrm{~h} / 12 \mathrm{~h}, 100 \mathrm{~W}$ bulb + UV lamp Repti-Glo, Hagen); the temperature ranged between 24 and $35{ }^{\circ} \mathrm{C}$ and air humidity between 60 and $80 \%$. The health status of the iguanas was monitored at regular intervals. The animals were clinically healthy and in good condition. One male iguana developed clinical signs of fibrous osteodystrophy at the age of 14 to 21 months. To eliminate a potential impact of the disease on haematological values, the iguana was excluded from the trial. The iguanas were fed every day. The diet consisted mainly of common dandelion leaves, Chinese cabbage, carrots, tomatoes, fruits, granulated food and cottage cheese.

Blood collection

When the iguanas were 14 to 36 months old, blood samples were taken every 30 or more days. Blood samples were collected from the ventral tail vein (vena coccygea ventralis), the animals were restrained manually, without sedation.

\section{Haemogram}

Blood smears were prepared immediately following the sample-taking; no anticoagulant was used. The blood smears were air-dried and stained with the Pappenheim method (May-Grünwald + Giemsa-Romanowski). Part of the blood was sampled into tubes containing sodium heparin (Heparin inj. Spofa). The total erythrocyte and leukocyte counts (RBC, WBC) were determined manually using haemocytometer with Natt and Herrick's solution; packed cell volume (PCV) was measured using the microhaematocrit method. Haemoglobin concentration $(\mathrm{Hb})$ was determined spectrophotometrically by using a standard cyanmethaemoglobin method with one modification: the samples were centrifuged following red cell lysis to remove the nuclear and cytoplasmic debris. The leukocyte differential counts were analyzed using an Olympus BX 51TF light microscope and documented with an Olympus C 3030 digital camera. Mean corpuscular volume (MCV), mean corpuscular haemoglobin (MCH) and mean corpuscular haemoglobin concentration (MCHC) were calculated.

Statistical analyses

The statistical assay analysis was performed using Stat Plus software (Stat Plus, version 1.01, 1990, VUVeL Brno, Czech Republic). Regression analysis was used to obtain a graphic representation of the development of the individual indices over time. To establish differences between individual sample-takings, the paired $t$-test was applied, while differences between males and females were established using the classic $t$-test. For the results to be valid, selected data sets were subjected to the Box-Cox transformation prior to testing to obtain a normal basic distribution.

\section{Results}

The total red blood cell count (RBC), haemoglobin concentration $(\mathrm{Hb})$, packed cell volume (PCV), mean corpuscular volume (MCV), mean corpuscular haemoglobin (MCH) and mean corpuscular haemoglobin concentration (MCHC) over the long period of time are stated in Table 1. Neither any seasonal change in these indices nor any differences between males and females were found. As to the number of erythrocytes, a statistically significant $(p<0.01)$ drop was observed comparing the figures at 14 to 15 months $\left(1.64 \pm 0.58 ; 1.17 \pm 0.1810^{12} / 1\right)$ with those at 34 to 36 months $\left(1.01 \pm 0.14 ; 0.88 \pm 0.12 ; 0.93 \pm 0.0810^{12} / 1\right)$. Likewise, a statistically 


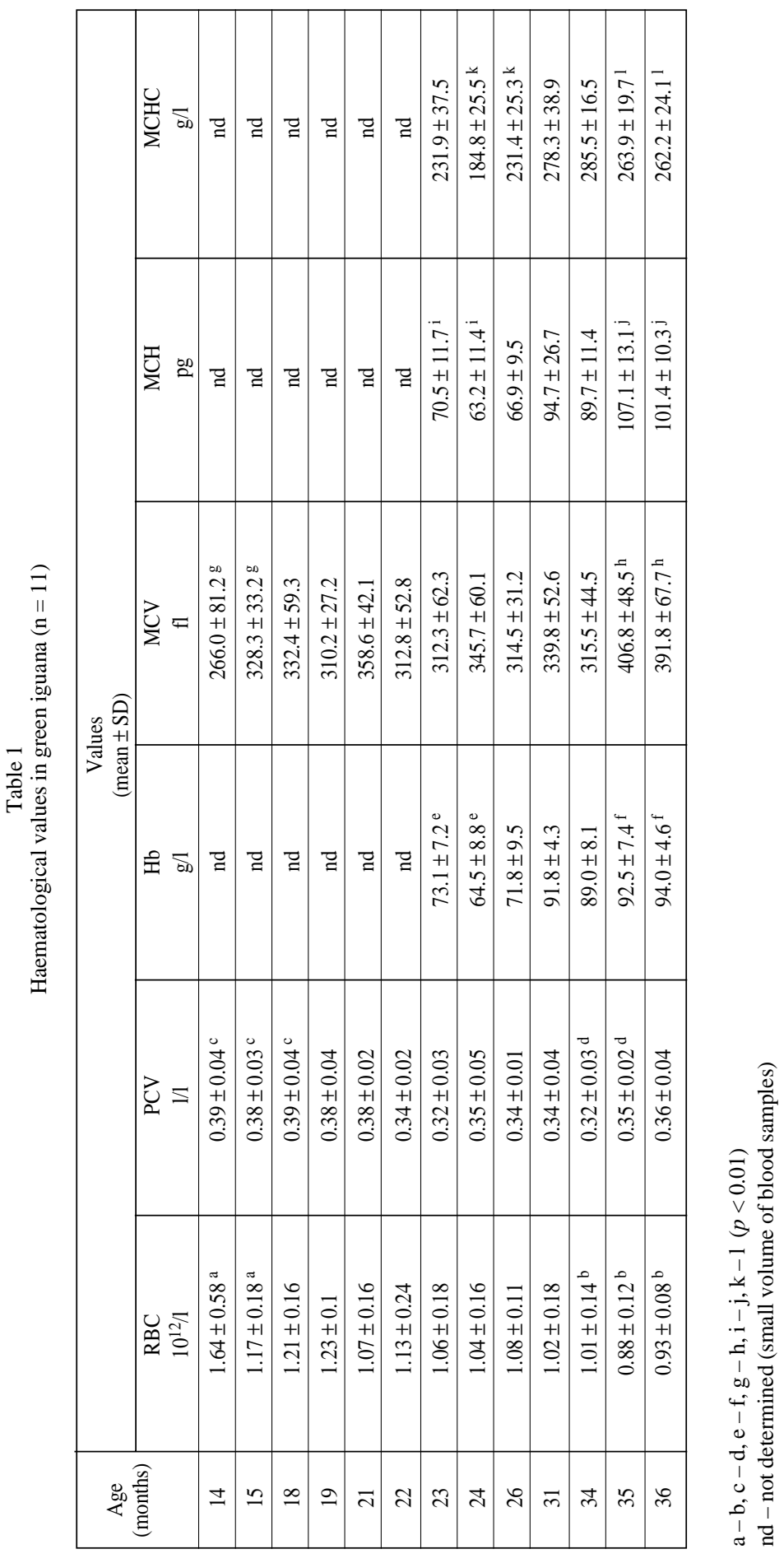




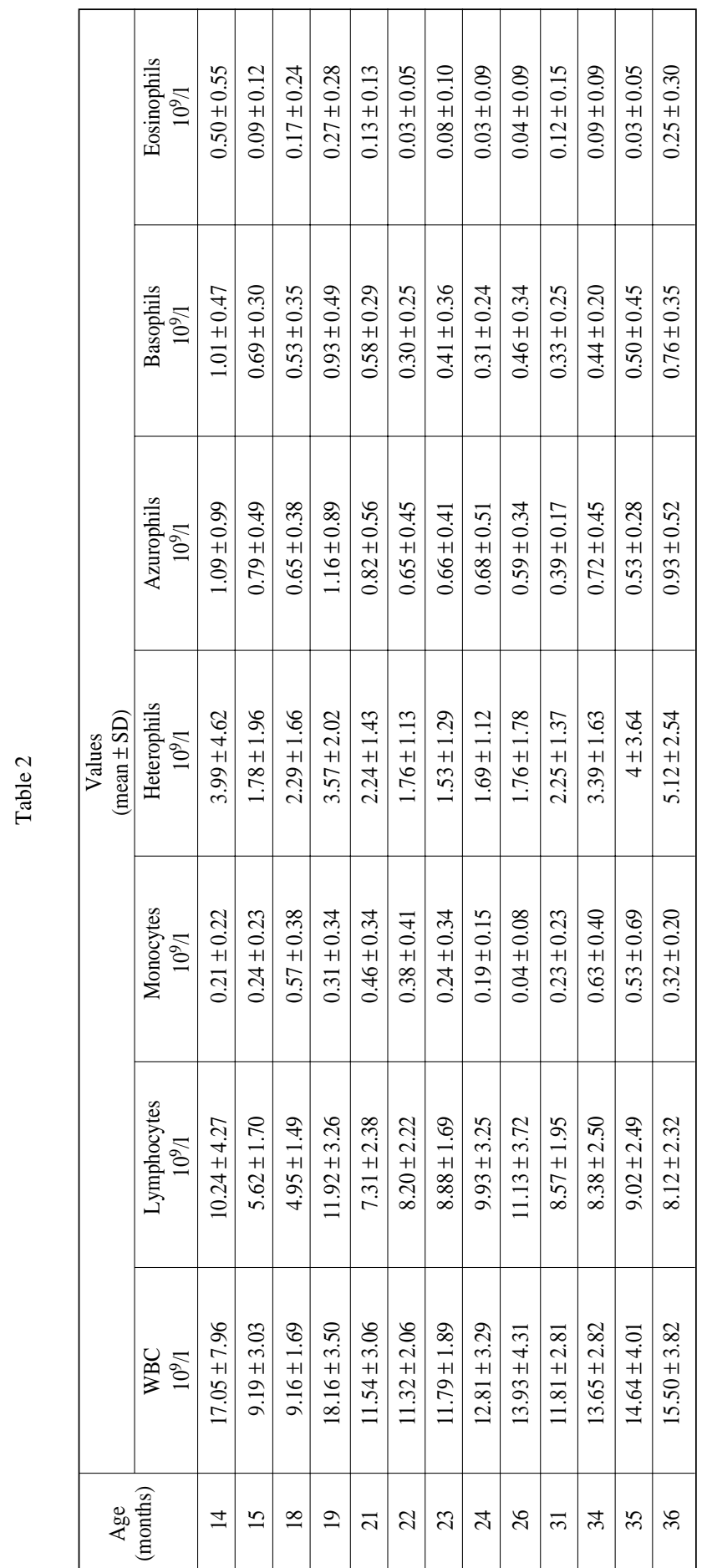

significant $(p<0.01)$ drop in packed cell volume was found comparing the figures obtained at 14 to 18 months of age of the animals (0.39 $\pm 0.04 ; 0.38 \pm 0.03 ; 0.39$ $\pm 0.04 \mathrm{l} / \mathrm{l})$ with those at 34 to 36 months $(0.32 \pm 0.03 ; 0.35$ $\pm 0.021 / 1)$. On the other hand, our results confirmed a statistically significant $(p<0.01)$ rise in haemoglobin concentration comparing the data at 23 to 24 months $(73.1 \pm 7.2$; $64.5 \pm 8.8 \mathrm{~g} / \mathrm{l})$ with those at 35 to 36 months $(92.5 \pm 7.4 ; 94.0$ $\pm \quad 4.6 \mathrm{~g} / \mathrm{l})$. A similar statistically significant increase $(p<0.01)$ was detected in erythrocyte indices $(\mathrm{MCV}, \mathrm{MCH}$, MCHC). The share of erythrocyte developmental forms in blood smears of the iguana population under investigation did not exceed two per cent. Erythrocyte inclusion bodies were found in five iguanas (two males and three females) repeatedly, their number not exceeding five per cent.

The trial revealed no significant differences in representation of the different leukocyte populations between male and female green iguanas. Total white blood cell count (WBC) and differential white blood cell counts over the long period of time are presented in Table 2.

\section{Discussion}

Reptiles are reported to show seasonal change of haematological values (Frye 1991). We have, however, recorded no seasonal change of haematological values in 
our population of green iguanas. We believe this is due to the constant conditions in which the animals were kept throughout the year as well as due to the biological specifics of the reptile species. The natural habitat of the subspecies Iguana iguana rhinolopha is Central America, from Mexico to Costa Rica, i.e. in a region with relatively constant temperature and light conditions (Frye and Townsend 1993; Köhler 1993). While periods of drought and rain take turns in nature, air humidity was kept within a constant range in our experimental conditions throughout the experiment. Harr et al. (2001) reported significantly higher haemoglobin oncentrations, PCV and MCHC in adult female iguanas compared with their male counterparts. Our trial revealed no significant differences between male and female subpopulations as to the haematological indices. Although the total red blood cell count was determined manually, the figures we have arrived at coincide with data obtained by other authors using automatic assays (Divers et al. 1996; Harr et al. 2001). Haemoglobin concentrations are almost identical, too. On the other hand, PCV, MCV, MCH and total white blood cell count in our trial were higher than figures published by Divers et al. (1996), but similar to figures measured by Harr et al. (2001).

While Divers et al. (1996) have come up with a one-off analysis of haematological values in 10 iguanas aged 1 to 5 years, Harr et al. (2001) contributed a similar analysis focusing on a group of 36 iguanas aged from 10 months to 7 years. Bruder (1998) has published a oneoff analysis of blood samples taken from 91 iguanas of both subspecies (Iguana iguana iguana, I. i. rhinolopha) of different ages and origins. Available information suggests that our trial has been the first long-term trial monitoring haematological parameters in green iguanas from a single clutch and kept at clearly defined conditions. What we believe is worth attention is the developmental trend revealed in the red blood cell population. The total red blood cell count (RBC) and the packed cell volume (PCV) showed a downward trend reaching the level of statistical significance when data obtained from the animals at 14 to 18 months of age were compared with data obtained at the age of 34 to 36 months. Conversely, haemoglobin concentration showed a marked upward trend reaching the level of statistical significance when data obtained from the animals at 23 to 24 months were compared with data obtained at 35 to 36 months. A similar statistically significant change was observed with erythrocyte indices (MCV, MCH, MCHC). We believe these changes may be the result of general physiological principles. The number of erythrocytes primarily corresponds to the metabolic activity, which is lower in adult animals than in the young. It has also been an established fact that reptiles with smaller erythrocytes have more of these cells in peripheral blood (Campbell 1996). There are cases when the direct correlation between haemoglobin concentration and PCV may be impaired (S y pek and B ory se nko 1988). In addition to that, there are proofs of correlation between reptile age and oxygen binding capacity of haemoglobin (Davies 1981). Whether the diminishing number of erythrocytes and the decreasing oxygen binding capacity of haemoglobin in the course of ontogenesis are compensated by growing haemoglobin concentrations remains to be established. Smears of reptile peripheral blood have been shown to contain microcytes, macrocytes (including binucleate cells) and poikilocytes. Anucleate erythrocytes (erythroplastids) or nuclei as such are less frequent (Frye 1991). There has been a trial that found a tiny amount of thus affected erythrocytes in blood of green iguanas; the share of immature blood cells did not exceed one per cent (Harr et al. 2001). The population of iguanas investigated by us had a similar share of these young cells. Intraerythrocytic inclusions are a relatively frequent finding in green iguanas, the fact having probably no clinical significance. Harr et al. (2001) report inclusions in $20 \%$ of erythrocytes. In the population of iguanas investigated by us, intraerythrocytic inclusions were found in $5 \%$ of cells.

Lymphocyte of green iguana varies in size between small, uniformly round and larger, and more pleomorphic mononuclear cells. They are characterized by light-blue to grey-blue 
cytoplasm and nuclei in the central position, differing - especially in the case of big lymphocytes- considerably in shape. In small lymphocytes, the cytoplasm forms only a tiny rim surrounding the round nucleus. A detailed examination may reveal azurophilic and/or hyaline inclusions. Some authors point out technical complications involved in distinguishing small lymphocytes from thrombocytes or big lymphocytes and monocytes (Bruder 1998; Harr et al. 2001). Our experience does not support the fear as the individual parts of the cells were easy to distinguish thanks to thorough preparation of blood films and Pappenheim staining. Thrombocytes of iguanas are relatively small basophilic elipsoidal cells with large, centrally located basophilic nuclei. While more immature cells tend to be round, mature thrombocytes are oval or irregular. The cytoplasm is pale blue or colourless and agranular. Thrombocytes usually aggregate in smears. As to the number of lymphocytes in green iguanas, the results of our trial coincide with the published study (Harr et al. 2001). Like these authors, we found lymphocytes to be the most prolific leukocyte population in periferal blood of healthy iguanas. Divers et al. (1996) report lower numbers of lymphocytes.

The heterophils in iguanas are characterized by oval or sharpened bright red cytoplasmic granules. The nucleus is bluish, in an off-centre position, mostly segmented. As to the number of heterophilic granulocytes, the results of our trial coincide with those of published studies (Divers et al. 1996; Harr et al. 2001). One peculiarity typical of green iguanas is the light-blue colour of the round cytoplasmic granules of the eosinophils (Hawkey and Dennett 1989). The nucleus is round to oval and situated in an off-centre position. The basophils in reptile blood smears stand out by their exquisite blue granules filling in the cytoplasm and concealing even the nucleus situated in the central position. There is a risk of diluting and washing away basophilic granules in case when inconsiderate sample processing is applied. Inconsistent classification of leukocytes with azurophilic granules in the cytoplasm has been a traditional issue in reptile haematology, surfacing as early as in relatively old publications (Saint Girons 1970; Sypek and Borysenko 1988). Green iguana monocytes are big mononuclear leukocytes with a slightly infolded to kidneyshaped, poorly stained nucleus and voluminous grey-blue cytoplasm containing fine azurophilic granules and scarce vacuoles. The azurophiles, too, are mononuclear cells with a dominantly stained nucleus mostly in an off-centre position and blue-grey cytoplasm containing prominent azurophilic granules. Differentiating between the two types of leukocytes in iguanas takes thorough preparation of samples and much experience on the part of the person doing the count. Their shares in peripheral blood differ depending on the reptile genus and species (Frye 1991; Campbell 1996; Mader 2000). Unlike our trial and the trial by Divers et al. (1996), Harr et al. (2001) did not regard the azurophils in green iguana as an independent leukocyte population. It may be attributed to this fact that including azurophiles in the monocyte category, they arrived at a higher number of monocytes.

The total number characterizing the different leukocyte populations showed no clear trend in the course of our trial. Although the data showed considerable variation, we found no statistically significant difference between individual sample-takings suggesting ontogenetic trends.

\section{Ontogeneze hematologických ukazatelů leguána zeleného (Iguana iguana rhinolopha)}

Většina hematologických sledování u leguánů zelených byla doposud uskutečněna jako vyhodnocení jednorázových odběrů krve. Cílem našeho projektu proto byla dlouhodobá ontogenetická studie uskutečněná u př́ibuzných zviŕat chovaných ve shodných podmínkách. Sledováno bylo 11 leguánů zelených (Iguana iguana rhinolopha), 5 samců a 6 samic, pocházejících z jedné společné snášky. Ještěři byli chováni v experimentálních teráriích 
$\mathrm{s}$ definovaným světelným režimem $(12 \mathrm{~h} / 12 \mathrm{~h})$, teplotou v rozmezí 24 - $35^{\circ} \mathrm{C}$ a vlhkostí vzduchu 60 - $80 \%$. Zdravotní stav leguánů byl opakovaně kontrolován. V období stáří leguánů 14 - 36 měsíců byly v intervalech minimálně 30 dnů prováděny opakované odběry krve. Stanovení celkového počtu erytrocytů a leukocytů se provádělo manuálně $\mathrm{s}$ použitím Nattova-Herrickova roztoku, hematokrit byl stanoven mikrohematokritovou metodou, koncentrace hemoglobinu se stanovovala fotometricky kyanhemoglobinovou metodou. Byl posouzen leukogram a vypočítány střední objem erytrocytu (MCV), hemoglobin erytrocytu $(\mathrm{MCH})$ a střední koncentrace hemoglobinu $\mathrm{v}$ erytrocytech (MCHC). Nebyly zjištěny sezónní změny hematologických ukazatelů. Nebyly potvrzeny signifikantní rozdíly sledovaných hematologických ukazatelů mezi samci a samicemi. V počtu červených krvinek byl prokázán statisticky významný pokles $(p<0.01)$ při porovnání hodnot ve stáři 14 - 15 měsíců $\left(1.640 .58 ; 1.17 \quad 0.1810^{12} / 1\right) \mathrm{s}$ hodnotami ve stáŕí 34 - 36 měsíců $\left(1.01 \pm 0.14 ; 0.88 \pm 0.12 ; 0.93 \pm 0.0810^{12} / 1\right)$. Také byl zaznamenán statisticky významný $(p<0.01)$ pokles hematokritu př́i porovnání hodnot ve stáří $14-18$ měsíců $(0.39 \pm 0.04 ; 0.38 \pm 0.03 ; 0.39 \pm 0.041 / 1)$ s hodnotami ve stáŕíi 34 - 35 měsíců $(0.32$ $\pm 0.03 ; 0.35 \pm 0.021 / 1)$. Naproti tomu vzestup se statistickou významností $(p<0.01)$ byl potvrzen pro koncentraci hemoglobinu při porovnání hodnot ve stáří 23 - 24 měsíců $(73.1$ $\pm 7.2 ; 64.5 \pm 8.8 \mathrm{~g} / \mathrm{l}) \mathrm{s}$ hodnotami ve stáří 35 - 36 měsíců $(92.5 \pm 7.4 ; 94.0 \pm 4.6 \mathrm{~g} / \mathrm{l})$. Obdobný statisticky významný vzestup $(p<0.01)$ byl potvrzen i pro vypočítané erytrocytární indexy (MCV, MCH, MCHC). Fyziologickou podstatu těchto změn je nutno dále prověřit.

\section{Acknowledgements}

We express our thanks for technical assistance to Šárka Trnková, Karolina Čechová and Jarmila Mužátková. The study was supported from a grant of the Ministry of Education, Youth and Sports (research project No. 161700002).

\section{References}

ANDERSON NL 1992: Diseases of Iguana iguana. Compend Cont Educ Pract Vet 14: 1335-1343

BARTEN SL 1993: The medical care of iguanas and other common pet lizards. Vet Clin N Amer 23: 1213-1249 BRUDER M 1998: Blutreferenzwerte bei Grünen Leguanen (Iguana iguana). Thesis, Univ München, 113 p. CAMPBELL TW 1996: Clinical pathology. In: MADER DR (Ed.): Reptile Medicine and Surgery. WB Saunders, Philadelphia, pp. 248-257

DAVIES PMC 1981: Anatomy and physiology. In: COOPER JE, JACKSON OF (Ed.): Diseases of the Reptilia. Academic Press, New York, Vol. 1, pp. 39-45

DIVERS SJ, REDMAYNE G, AVES EK 1996: Haematological and biochemical values of 10 green iguanas (Iguana iguana). Vet Rec 138: 203-205

FRYE FL 1991: Haematology as applied to clinical reptile medicine. In: Reptile Care. An Atlas of Diseases and Treatment. TFH Publications Inc., Neptune City, New Jersey, pp. 211-277

FRYE FL, TOWNSEND W 1993: Iguanas. A guide to their biology and captive care. Krieger Publishing Comp., Malabar, $145 \mathrm{p}$.

HARR KE, ALLEMAN AR, DENNIS PM, MAXWELL LK, LOCK BA, BENNET RA, JACOBSON ER 2001:

Morphologic and cytochemical characteristics of blood cells and haematologic and plasma biochemical reference in green iguanas. J Amer Vet Med Assoc 218: 915-921

HAWKEY CM, DENNETT TB 1989: Color atlas of comparative veterinary haematology. Wolfe Med Publ, $192 \mathrm{p}$.

KNOTEK Z, HAUPTMAN K, KNOTKOVÁ Z, HÁJKOVÁ P, TICHÝ F 2002: Haemogram and plasma biochemistry in green iguanas with renal disease. Acta Vet Brno 71: 333-340

KNOTEK Z, KNOTKOVÁ Z, DOUBEK J, PEJŘILOVÁ S, HAUPTMAN K 2003: Plasma Biochemistry in Female Green Iguanas (Iguana iguana) with Calcium Metabolism Disorders. Acta Vet Brno 72: 183-189 KÖHLER G 1993: Der Grüne Leguan. G. Köhler Verlag, Hanau, 118 p. KÖHLER G 1996: Krankheiten der Amphibien und Reptilien. Eugen Ulmer Verlag, 166 p.

MADER DR 2000: Normal Haematology of Reptiles. In: FELDMAN BF, ZINKL JG, JAIN NC (Ed.): Schalm's Veterinary Haematology. 5th ed., Lippincott, Williams and Wilkins, Baltimore, pp. 1126-1132 REDROBE S, MacDONALD J 1999: Sample collection and clinical pathology of reptiles. Vet Clin N Amer 2: $709-730$ 
SAINT GIRONS MC 1970: Morphology of the circulating blood cells. In: GANS C, PARSONS TS (Ed.): Biology of the Reptilia, vol. 3 - Morphology C, Academic Press London, pp. 73-91

SYPEK J, BORYSENKO M 1988: Reptiles. In: ROWLEY AF, RATCLIFFE NA (Ed).: Vertebrate blood cells. Cambridge Univ Press, Cambridge, pp. 211-256

WALTON RM 2001: Establishing Reference Intervals. Health as a relative Concept. In: FUDGE AM (Ed.):

Seminars in Avian and Exotic Pet Medicine, Challenges in Laboratory Diagnostics, W. B. Saunders, Philadelphia 10: 66-71 